\title{
FAKTOR-FAKTOR YANG MEMPENGARUHI KEPUTUSAN PETANI BERMITRA DENGAN PT. SIRTANIO ORGANIK INDONESIA
}

\author{
Fakhruddin Yulistiono", Triana Dewi Hapsari \\ Program Studi Agribisnis, Fakultas Pertanian, Universitas Jember \\ J1. Kalimantan No. 37 Kampus Tegalboto Sumbersari Jember \\ *Corresponding author: fakhruddinyulis@gmail.com
}

\begin{abstract}
This study aims to determine the characteristics of farmers and the factors that influence the decision of farmers to partner with PT. Sirtanio Organik Indonesia. The research method used is descriptive analytic. Determination of the location of the study was done intentionally at PT. Sirtanio Organik Indonesia. The sampling method in this study uses total sampling. The data used in this study are primary data as primary data and secondary data as supporting data. Data collection techniques are carried out by observation, interviews and documentation. The results showed that the socio-economic and ecological characteristics of partner farmers PT. Organic Sirtanio Indonesia is mostly men in productive age with the same level of primary education as having family members of 3 to 4 people, having enough experience with the status of their own land but still in a narrow category and getting capital from personal funds and credit from PT. Sirtanio Organik Indonesia and the condition of land that has fulfilled the requirements to apply organic farming. Factors that significantly influence the decision of farmers to partner with PT. Sirtanio Organik Indonesia, namely age, education, land area and income.
\end{abstract}

Keywords: farmer characteristics, farmer decisions, partnership

\begin{abstract}
Abstrak: Penelitian ini bertujuan untuk mengetahui karakteristik petani dan faktorfaktor yang mempengaruhi keputusan petani untuk bermitra dengan PT. Sirtanio Organik Indonesia. Metode penelitian yang digunakan adalah deskriptif analitik. Penentuan lokasi penelitian dilakukan secara sengaja yaitu pada PT. Sirtanio Organik Indonesia. Metode pengambilan sampel dalam penelitian ini menggunakan total sampling. Data yang digunakan pada penelitian ini yaitu data primer sebagai data utama dan data sekunder sebagai data pendukung. Teknik pengumpulan data dilakukan dengan observasi, wawancara dan dokumentasi. Hasil penelitian menunjukkan bahwa Karakteristik sosial ekonomi dan ekologi petani mitra PT. Sirtanio Organik Indonesia sebagian besar adalah laki-laki di usia produktif dengan jenjang pendidikan SD sederajat memiliki jumlah anggota keluarga 3 hingga 4 orang, memiliki cukup pengalaman dengan status lahan milik sendiri namun masih dalam kategori sempit serta mendapatkan modal dari dana pribadi dan kredit PT. Sirtanio Organik Indonesia serta kondisi lahan yang sudah memenuhi syarat untuk menerapkan pertanian organik. Faktor-faktor yang signifikan berpengaruh terhadap keputusan petani bermitra dengan PT. Sirtanio Organik Indonesia yaitu umur, pendidikan, luas lahan dan pendapatan.
\end{abstract}

Kata Kunci: karakteristik petani, kemitraan, keputusan petani

\section{PENDAHULUAN}

Pertanian organik menurut IFOAM (The International Federation of Organic Agriculture
Movements) didefinisikan sebagai sistem manajemen produksi holistik yang meningkatkan dan mengembangkan kesehatan ekosistem, termasuk siklus biologi dan aktivitas 
biologi tanah. Dari segi keamanan pangan, produk organik tidak menggunakan bahan pembasmi sintetis untuk hama dan penyakit, sehingga manusia terbebas dari dampak negatif akumulasi residu bahan sintetis tersebut dalam tubuhnya. (Suhardianto, 2007).

Kabupaten Banyuwangi merupakan salah satu kabupaten di Provinsi Jawa Timur yang menerapkan sistem pertanian organik. Salah satu perusahaan swasta di Kabupaten Banyuwangi yang bergerak di bidang pertanian organik yaitu PT. Sirtanio Organik Indonesia. PT. Sirtanio Organik Indonesia melakukan usahanya secara terintegrasi dari hulu (on farm) hingga hilir (off farm). Sebagai perusahaan pertanian organik yang terintegrasi dari hulu sampai hilir.

PT. Sirtanio Organik Indonesia dalam pemenuhan produksinya bermitra dengan petani. Petani mitra PT. Sirtanio Organik Indonesia tersebar di beberapa desa yang berbeda, dan setiap petani pun memiliki karakteristik yang berbeda. Menurut Rodgers (1983) menyatakan bahwa karakteristik seseorang akan mempengaruhi tindakan dan perilaku orang tersebut sehingga dapat memberikan pengaruh terhadap pengambilan keputusan petani dalam bermitra. Sistem kemitraan yang dilakukan oleh PT. Sirtanio Organik Indonesia adalah sistem kemitraan kontrak dimana petani dikontrak untuk bermitra hanya dalam sekali musim tanam, jika petani ingin bermitra kembali dengan PT. Sirtanio Organik Indonesia maka petani harus mendaftar lagi untuk menjadi mitra pada musim tanam berikutnya. Sistem kemitraan tersebut membuat jumlah petani mitra PT. Sirtanio Organik Indonesia tidak tetap pada setiap musim tanamnya. Oleh karena itu, peneliti ingin mengetahui secara mendetail mengenai karakterisktik petani mitra sehingga dapat mengetahui alasan yang mendasari keputusan petani untuk bermitra dengan PT. Sirtanio Organik Indonesia. Karakteristik dapat dijadikan sebagai penunjang untuk menganalisis secara menyeluruh faktor-faktor yang mempengaruhi keputusan petani bermitra dengan PT. Sirtanio Organik Indonesia.

\section{METODE PENELITIAN}

Penentuan daerah penelitian secara sengaja dengan pertimbangan bahwa Kabupaten
Banyuwangi merupakan kabupaten yang menduduki peringkat ke 10 se-Indonesia untuk lahan pertanian organik. PT. Sirtanio Organik Indonesia dipilih dengan pertimbangan bahwa PT. Sirtanio Organik Indonesia adalah produsen beras organik yang memiliki mitra di Kabupaten Banyuwangi, Kabupaten Bondowoso dan Kabupaten Jember. Kabupaten Banyuwangi merupakan daerah dengan jumlah mitra terbanyak dan luas lahan terbesar yaitu sebesar 45 ha.

Metode yang digunakan dalam penelitian ini adalah metode deskriptif dan analitik. Analisis deskriptif digunakan untuk menjelaskan karakteristik sosial ekonomi dan ekologi petani mitra PT. Sirtanio Organik Indonesia. Analisis secara analitik dilakukan untuk mengetahui faktor-faktor yang mempengaruhi keputusan petani bermitra dengan PT. Sirtanio Organik Indonesia.

Penentuan sampel petani mitra dan non mitra PT. Sirtanio Organik Indonesia menggunakan sampling jenuh. Menurut Sugiyono (2016), metode sampling jenuh adalah teknik penentuan sampel bila semua anggota populasi digunakan sebagai sampel. Populasi yang dijadikan sampel adalah petani organik mitra dan non mitra PT. Sirtanio Organik Indonesia pada musim tanam satu yaitu pada bulan Desember hingga bulan Maret tahun 2018 populasi petani mitra berjumlah 45 petani dan populasi petani non mitra berjumlah 10 petani. Pengambilan sampel jenuh juga diharapkan mampu memberikan data yang representatif untuk menggambarkan keadaan di lapang.

Metode pengumpulan data yang digunakan oleh peneliti meliputi metode observasi, metode wawancara, dan metode dokumentasi. Metode wawancara terstruktur dilakukan setelah peneliti mengetahui mengenai informasi apa yang akan diperoleh (Sugiyono, 2016). Metode dokumentasi merupakan teknik pengumpulan data dengan cara mencari bukti-bukti terkait objek yang diteliti yang berupa gambar atau tulisan. Metode observasi adalah metode pengumpulan data dan informasi yang dilakukan dengan objek-objek alam, perilaku manusia, proses kerja, dan responden yang diamati tidak terlalu besar (Sugiyono, 2016).

Karakteristik petani mitra PT. Sirtanio Organik Indonesia dianalisis menggunakan 
analisis deskriptif. Analisis deskriptif digunakan untuk menjelaskan karakteristik sosial, ekonomi, dan ekologi petani mitra PT. Sirtanio Organik Indonesia.

Untuk mengetahui faktor-faktor yang mempengaruhi keputusan petani bermitra dengan PT. Sirtanio Organik Indonesia menggunakan analisis Regresi logistik yang didukung dengan program SPSS 23 for Windows. Regresi logistik merupakan salah satu model statistika yang dapat digunakan untuk menganalisis pola hubungan antara sekumpulan variabel independen dengan suatu variabel dependen bertipe kategoris atau kualitatif (Rosadi, 2011). Menurut Gani dan Amalia (2015) Formulasi persamaan model regresi logistik ditampilkan dalam persamaan 1

\section{HASIL DAN PEMBAHASAN}

Karakteristik petani mitra PT. Sirtanio Organik Indonesia yang akan dibahas meliputi karakter sosial, ekonomi dan ekologi dimana pada karakter sosial akan dibahas umur, tingkat pendidikan, jumlah anggota keluarga, dan pengalaman. Karakter ekonomi yang akan dibahas adalah luas lahan dan sumber modal serta karakteristik ekologi yang akan dibahas adalah kondisi lahan.

\section{Umur}

Rata-rata umur responden dalam penelitian ini adalah 47 tahun dengan umur responden termuda 28 tahun dan umur responden tertua 62 tahun. Menurut Soekartawi (1988), seseorang yang memiliki umur yang muda cenderung memiliki semangat dan memiliki daya keingintahuan yang lebih tinggi dari pada orang yang sudah berumur tua ( $>50$ tahun). Semangat dan keingintahuan yang tinggi tersebut akan mendorong seseorang untuk belajar dan mencari informasi serta mencoba untuk melakukan eksperimen-eksperimen. Dengan demikian, seseorang yang masih muda $(<50$ tahun) lebih cepat mengadopsi inovasi meskipun orang tersebut belum memiliki pengalaman mengenai inovasi yang ada. Usia yang dimiliki oleh petani mitra PT. Sirtanio Organik Indonesia membuat petani mitra mampu menerima inovasi baru yang dapat meningkatkan produksi padi mereka, umumnya petani muda masih mampu menerima inovasi baru dalam meningkatkan produksi dari kegiatan produktif yang dilakukannya dan memiliki kemungkinan yang besar untuk mengambil keputusan melakukan usahatani yang dapat memberikan manfaat paling besar.

\section{Tingkat Pendidikan}

Diketahui bahwa sebaran tingkat pendidikan formal terakhir petani mitra PT. Sirtanio Organik Indonesia sebagian besar masih didominasi oleh petani lulusan Sekolah Dasar (SD) sederajat yaitu sebanyak 19 petani dari 45 responden atau sebesar 42 persen, diikuti dengan petani mitra lulusan SMP sederajat sebesar 27 persen sejumlah 12 petani, kemudian sebanyak 8 petani (18 persen) lulusan Sekolah Menengah Atas sederajat, 5 petani (11 persen) tidak tamat SD dan pendidikan tertinggi sebanyak 1 petani (2 persen) lulusan Strata 1. Petani mitra yang tidak tamat SD sebagian besar merupakan petani yang berusia lanjut dan memang dari keluarga yang kurang mampu sehingga pendidikan belum dianggap sebagai kebutuhan primer. Sektor budidaya pertanian memang hingga saat ini masih didominasi oleh lulusan SD karena memang petani mitra PT. Sirtanio Organik Indonesia merupakan keluargaa yang kurang mampu sehingga sekolah atau pendidikan belum merupakan kebutuhan primer mereka. Menurut Soekartawi (1988), Seseorang yang memiliki pendidikan lebih tinggi akan cenderung lebih cepat mengadopsi inovasi daripada yang berpendidikan lebih rendah. Seseorang yang memiliki pendidikan lebih tinggi akan memiliki pengetahuan dan wawasan yang lebih luas, sehingga cenderung lebih terbuka terhadap hal baru dan lebih cepat dalam menyikapi perubahan yang terjadi akibat penerapan suatu inovasi.

\section{Jumlah Anggota Keluarga}

Jumlah anggota petani mitra PT. Sirtanio Organik Indonesia sebagian besar 3-4 orang dan hanya sedikit petani mitra yang memiliki jumlah anggota keluarga lebih dari 4 orang hal ini dikarenakan petani yang memiliki banyak anggota keluarga belum begitu berani mengambil resiko untuk bermitra dan menerapkan pertanian organik dikarenakan pada masa transisi hasil produksi akan turun yang akan berpengaruh terhadap pendapatan petani untuk memenuhi kebutuhan keluarganya. 
Keterangan:

$Y_{i} \quad=$ Keputusan petani padi organik $1=$ Jika petani bermitra dengan PT. Sirtanio Organik

$\beta_{0} \quad=$ konstanta

$\beta_{1}-\beta_{7} \quad=$ koefisien regresi variabel independen

$\mathrm{X}_{1} \quad=$ Umur petani (Tahun)

$\mathrm{X}_{2} \quad=$ Pendidikan petani (Tahun)

$\mathrm{X}_{3} \quad=$ Pengalaman petani (Tahun)

$\mathrm{X}_{4} \quad$ = Jumlah anggota keluarga (Jiwa)

$\mathrm{X}_{5} \quad=$ Luas lahan $(\mathrm{Ha})$

$\mathrm{X}_{6} \quad=$ Pendapatan $(\mathrm{Rp} / \mathrm{MT} / \mathrm{Ha})$

$\mathrm{D}_{7} \quad=$ Pelatihan $(1=$ Pernah, $0=$ Tidak Pernah $)$

$\mathrm{D}_{8} \quad=$ Kondisi lahan (1=Layak, $0=$ Tidak Layak $)$

Hal ini selaras dengan Soekartawi (1988) yang menyatakan bahwa kebanyakan petani kecil agak lamban dalam mengubah sikapnya terhadap perubahan. Hal ini disebabkan karena sumberdaya yang mereka miliki terbatas sekali. Hal tersebut membuat mereka agak sulit untuk mengubah sikapnya untuk mengadopsi inovasi. Mereka khawatir kalau adopsi inovasi tersebut ternyata gagal, mereka akan sulit untuk mendapatkan atau mencukupi makan anggota keluarganya.

\section{Pengalaman}

Pengalaman merupakan lamanya petani mitra PT. Sirtanio Organik Indonesia dalam menerapkan pertanian padi organik di lahan yang mereka miliki. Sebagian besar petani mitra yakni 27 orang (60 persen) telah memiliki pengalaman dalam budidaya padi organik selama 2 hingga 3 tahun. Sebanyak 10 orang (22 persen) memiliki pengalaman budidaya padi organik kurang dari 2 tahun, dan 8 orang responden (18 persen) memiliki pengalaman budidaya padi organik lebih dari 3 tahun. Hasil penelitian lapang menunjukkan bahwa hanya 10 petani (22 persen) petani dengan pengalaman usahatani $<2$ tahun, sementara 35 petani lainnya memiliki pengalaman yang sudah lebih tinggi yaitu 2 tahun hingga lebih dari 3 tahun. Hal tersebut menunjukkan bahwa petani mitra PT. Sirtanio Organik Indonesia sudah cukup lama menekuni usahatani padi organik sehingga petani mitra dapat belajar dari pengalamannya dalam berusahatani padi organik melalui serangkaian kegiatan yang pernah dialaminya.

\section{Luas Lahan}

Luas lahan yang dimiliki oleh sebagian besar petani mitra PT. Sirtanio Organik Indonesia merupakan lahan dengan luasan kurang dari 0,5 ha atau masuk dalam kategori sempit, hal ini disebabkan karena banyak lahan petani mitra yang berada dibawa kaki gunung raung hal ini dikarenakan syarat untuk menjadi petani mitra PT. Sirtanio Organik Indonesia salah satunya adalah saluran irigasi harus berasal dari sumber mata air atau jika tidak berasal dari sumber mata air petani harus membuat filter atau bak penyaring air di lahan milik mereka agar residu pada air irigasi dapat dikurangi.

\section{Sumber Modal}

Sumber modal yang digunakan oleh petani mitra PT. Sirtanio Organik Indonesia dapat berasal dari 2 sumber yaitu dari modal pribadi dan modal dari kredit saprodi oleh PT. Sirtanio Organik Indonesia. Modal sendiri yang dikeluarkan oleh petani mitra berupa biaya tetap dan biaya tenaga kerja, sedangkan PT. Sirtanio Organik Indonesia memberikan kredit berupa kebutuhan saprodi mulai dari benih, pupuk, dan agen hayati. Semua kebutuhan tersebut diberikan PT. Sirtanio Organik Indonesia sesuai dengan kebutuhan petani dan dibayarkan nanti pada saat petani mitra yang mengambil kredit telah panen. 
Fakhruddin Y., Triana D. H.: Faktor-Faktor yang Mempengaruhi ...

Tabel 1. Hasil uji regresi logistik faktor-faktor yang mempengaruhi petani untuk bermitra dengan PT. Sirtanio Organik Indonesia.

\begin{tabular}{|c|c|c|c|c|c|c|}
\hline Variabel Bebas & B & S.E. & Wald & df & Sig. & $\operatorname{Exp}(B)$ \\
\hline Umur (X1) &,$- 163 *$ & ,093 & 3,096 & 1 & ,078 &, 850 \\
\hline Pendidikan (X2) &,$- 518 *$ & ,285 & 3,304 & 1 & 069 &, 596 \\
\hline Pengalaman (X3) & 895 & ,763 & 1,376 & 1 & 241 & 2,446 \\
\hline Jumlah Anggota Keluarga (X4) & 125 & ,726 & 030 & 1 & 863 & 1,133 \\
\hline Luas Lahan (X5) & $-12,552 *$ & 6,242 & 4,043 & 1 & 044 & 005 \\
\hline Pendapatan (X6) &, $644 *$ & ,373 & 2,986 & 1 & 084 & 1,904 \\
\hline Pelatihan (D7) & $-1,181$ & 1,389 &, 724 & 1 & ,395 & ,307 \\
\hline Kondisi Lahan (D8) & ,348 & 1,109 & ,098 & 1 & ,754 & 1,416 \\
\hline Konstanta & 13,114 & 5,750 & 5,202 & 1 & ,023 & $495.975,145$ \\
\hline
\end{tabular}

Sumber : Data Primer (diolah), 2018

Keterangan:

B : Koefisien Regresi

S.E $\quad$ : Standar Error

Wald : Nilai Wald

Df : Derajat bebas

Sig. : Nilai Signifikansi

$\operatorname{Exp}(B)$ : Nilai Odd Ratio

*) $\quad$ : Signifikansi pada taraf kepercayaan $90 \%$

$\mathrm{Yi}=\frac{\mathrm{e}^{13,114-0,163 \mathrm{X} 1-0,518 \times 2+0,895 \times 3+0,125 \times 4-12,552 \mathrm{XX}+0,644 \mathrm{X} 6-1,181 \mathrm{D} 7+0,348 \mathrm{D} 8}}{1+\mathrm{e}^{13,114-0,163 \mathrm{X} 1-0,518 \times 2+0,895 \mathrm{X} 3+0,125 \mathrm{X} 4-12,552 \mathrm{X} 5+0,644 \mathrm{X} 6-1,181 \mathrm{D} 7+0,348 \mathrm{D} 8}}$

\section{Kondisi Lahan}

Sumber air petani mitra PT. Sirtanio Organik Indonesia terbagi menjadi dua yaitu berasal dari sumber dan air dari saluran sekunder. Sumber air merupakan salah satu syarat untuk menjadi petani mitra PT. Sirtanio Organik Indonesia, petani yang lahannya berada dibawah kaki gunung biasanya menggunakan aliran air yang berasal dari sumber untuk mengairi lahannya hal ini baik untuk menjaga ekosistem yang sudah ada, namun petani mitra yang menggunakan sumber sekunder mereka menggunakan filter yang dibangun pada lahan mereka yang bertujuan untuk mengurangi residu yang masuk ke lahan sehingga ekosistem lahan dan lingkungan dapat terjaga.

Faktor - Faktor yang Mempengaruhi Keputusan Petani Bermitra dengan PT. Sirtanio Organik Indonesia

Faktor - faktor yang mempengaruhi keputusan petani untuk bermitra perlu diketahui secara jelas, tujuannya agar dalam pelaksanaan kemitraan yang akan datang dapat berkelanjutan dengan diketahui faktor-faktor yang berpengaruh secara nyata atau tidak nyata dalam pengambilan keputusan petani untuk bermitra dengan PT. Sirtanio Organik Indonesia. Guna membuktikan faktor-faktor yang mempengaruhi keputusan petani untuk bermitra maka perlu dilakukan analisis pengambilan keputusan menggunakan model regresi logistik.

Berdasarkan Tabel 1. menunjukkan bahwa dari delapan variabel di dalam model, terdapat empat variabel yang berpengaruh signifikan terhadap pengambilan keputusan petani untuk bermitra. Keempat variabel tersebut adalah umur (X1), pendidikan (X2), luas lahan (X5), dan pendapatan (X6) karena memiliki nilai signifikansi $<0,1$. Variabel lain yaitu pengalaman (X3), jumlah anggota keluarga (X4), pelatihan (D7), dan kondisi lahan (D8) tidak berpengaruh signifikan terhadap pengambilan keputusan petani untuk bermitra karena memiliki nilai signifikansi $>0,1$. Model persamaan regresi logistik yang diperoleh berdasarkan Tabel 1 seperti pada persamaan 2 . 
Fakhruddin Y., Triana D. H.: Faktor-Faktor yang Mempengaruhi ...

Penjelasan masing-masing variabel independen yang telah diuji secara terperinci adalah sebagai berikut:

\section{Umur}

Faktor umur memiliki nilai signifikansi sebesar 0,078 (< 0,1). Hal ini menunjukkan bahwa umur petani berpengaruh nyata terhadap pengambilan keputusan petani untuk bermitra. Umur memiliki nilai koefisien regresi yang negatif sebesar $-0,163$, nilai negatif tersebut dapat diartikan bahwa setiap penambahan umur petani sebesar 1 tahun, maka akan menurunkan peluang petani untuk bermitra, sebaliknya semakin muda umur yang dimiliki petani maka kecenderungan petani untuk bermitra juga akan semakin meningkat. Hasil tersebut sesuai dengan pendapat Soekartawi (1988), dimana seseorang yang memiliki umur yang muda cenderung memiliki semangat dan memiliki daya keingintahuan yang lebih tinggi dari pada orang yang sudah berumur tua ( $>50$ tahun). Semangat dan keingintahuan yang tinggi tersebut akan mendorong seseorang untuk belajar dan mencari informasi serta mencoba untuk melakukan eksperimen-eksperimen. Dengan demikian, seseorang yang masih muda ( $<50$ tahun) lebih cepat mengadopsi inovasi meskipun orang tersebut belum memiliki pengalaman mengenai inovasi yang ada. Petani yang memiliki umur lebih muda cenderung memiliki rasa ingin tahu yang besar dan ingin merasakan dampak dari suatu kemitraan.

\section{Pendidikan}

Nilai signifikansi sebesar $0,069(<0,1)$ dan nilai koefisien regresi bernilai negatif $(-0,518)$. Hal ini memiliki pengertian bahwa pendidikan petani berpengaruh terhadap pengambilan keputusan petani untuk bermitra. Nilai koefisien regresi yang bernilai negatif dapat diartikan bahwa semakin tinggi tingkat pendidikan petani, maka akan menurunkan peluang petani untuk bermitra atau dengan kata lain petani yang memiliki pendidikan lebih rendah cenderung memilih untuk bermitra. Hal ini dikarenakan berdasarkan hasil lapang petani yang memiliki pendidikan rendah cenderung lebih mengandalkan pendidikan non formal seperti pelatihan dan penyuluhan, selain itu sebagian besar petani mitra berasal dari keluarga tidak mampu sehingga pendidikan bukanlah kebutuhan primer, namun petani mitra masih memiliki semangat untuk mencari informasi terbaru seputar pertanian.

\section{Pengalaman}

Pengalaman memiliki nilai signifikansi sebesar $0,241(>0,1)$ hal ini menunjukkan bahwa pengalaman merupakan salah satu faktor yang tidak berpengaruh signifikan terhadap keputusan petani untuk bermitra. Pengalaman tidak berpengaruh signifikan terhadap keputusan petani untuk bermitra dikarenakan pada kondisi di lapang dimana sebagian besar pengalaman petani mitra PT. Sirtanio Organik Indonesia memiliki pengalaman lebih dari 2 tahun harus rela tidak bermitra dalam sekali musim tanam dalam setahun dikarenakan faktor alam, walaupun begitu petani yang tidak bermitra pada musim tanam dua tidak menggunakan lahan mereka untuk menanam komoditas lain tetapi diberokan atau tidak ditanami komoditas lain. Hal ini dilakukan agar lahan mereka tetap memenuhi syarat jika bermitra dengan PT. Sirtanio Organik Indonesia pada musim tanam selanjutnya.

\section{Jumlah Anggota Keluarga}

Jumlah anggota keluarga memiliki nilai signifikansi sebesar 0,863 (> 0,1), hal ini menunjukkan jumlah anggota keluarga adalah salah satu faktor yang tidak berpengaruh signifikan terhadap pengambilan keputusan petani untuk bermitra. Jumlah anggota keluarga tidak berpengaruh signifikan terhadap keputusan petani dikarenakan pada kondisi lapang petani masih memikirkan resiko yang timbul yaitu dalam hal resiko produksi karena saat masa konversi dari pertanian konvensional ke pertanian organik akan ada resiko penurunan produksi. Hal ini sejalan dengan Soekartawi (1988), bahwa kebanyakan petani kecil agak lamban dalam mengubah sikapnya terhadap perubahan. Hal ini disebabkan sumberdaya yang dimiliki terbatas. Hal tersebut membuat mereka agak sulit untuk mengubah sikapnya untuk mengadopsi inovasi. Mereka khawatir kalau adopsi inovasi tersebut ternyata gagal. Sebab sekali adopsi inovasi itu gagal, sulit mendapatkan atau mencukupi makan anggota keluarga.

\section{Luas Lahan}

Nilai signifikansi dari faktor luas lahan $\left(\mathrm{X}_{5}\right)$ sebesar $0,044(<0,1)$ dengan nilai koefisien 
regresi bernilai negatif $(-12,552)$. Hal ini menunjukkan bahwa luas lahan berpengaruh signifikan terhadap keputusan petani untuk bermitra. Koefisien regresi yang bernilai negatif menunjukkan jika semakin luas lahan yang dimiliki petani maka akan menurunkan peluang petani untuk bermitra. Hal ini sesuai dengan kondisi dilapang rata-rata luas lahan petani yang bermitra adalah $0,44 \mathrm{Ha}$. Luas lahan petani yang bermitra cenderung sempit hal ini dikarenakan syarat-syarat yang harus dipenuhi oleh petani yang ingin menjadi petani mitra yaitu memiliki saluran irigasi yang berasal dari sumber air atau jika aliran irigasi merupakan saluran sekunder maka harus membuat filter pada lahan petani mitra. Lahan petani mitra yang sempit dikarenakan memang hanya lahan tersebut yang memenuhi syarat untuk bermitra dengan PT. Sirtanio Organik Indonesia.

\section{Pendapatan}

Pendapatan memiliki nilai signifikansi sebesar $0,084(<0,1)$ sehingga dapat diartikan bahwa faktor pendapatan merupakan faktor yang mempengaruhi keputusan petani untuk bermitra. Nilai koefisien regresi pendapatan bernilai positif $(0,348)$ yang artinya setiap peningkatan pendapatan yang diperoleh oleh petani maka akan meningkatkan peluang petani untuk bermitra. Menurut Mubyarto (1995), faktor yang mempengaruhi kehidupan dan perilaku petani yaitu keberhasilan produksi dan tingkat harga. Semakin tinggi harga dan pendapatan maka semakin mendorong petani untuk berproduksi dan mengembangkan usahataninya juga semakin tinggi pula, sehingga untuk lebih mengembangkan usahataninya petani membutuhkan modal yang lebih besar dan kepastian harga untuk meningkatkan keuntungan usahataninya. Hal ini sesuai dengan kondisi lapang dimana pada petani mitra, ada beberapa hal yang diatur dalam kontrak yang dianggap menguntungkan bagi petani yaitu adanya kontrak harga dimana pada kontrak harga ini petani sudah pasti mendapatkan jaminan harga Rp. 200 diatas harga pasar. Jika harga gabah naik maka harga dalam kontrak juga ikut naik namun jika harga gabah turun maka harga kontrak akan tetap pada kesepakatan diawal yang sudah disepakati. Keuntungan lain yang didapatkan yaitu adanya pinjaman modal dari pihak PT.
Sirtanio Organik Indonesia. Hal ini membuat biaya yang dikeluarkan petani mitra lebih rendah sehingga pendapatan petani meningkat dan mempengaruhi keputusan petani.

\section{Pelatihan}

Pelatihan yang dimaksud dalam penelitian ini merupakan variabel dummy $(0=$ tidak pernah mengikuti pelatihan, $1=$ pernah mengikuti pelatihan). Nilai signifikansi sebesar 0,307 (> $0,1)$. Hal ini menunjukkan jika pelatihan adalah faktor yang juga tidak berpengaruh terhadap keputusan petani untuk bermitra. Faktor pelatihan tidak berpengaruh terhadap pengambilan keputusan petani dikarenakan memang setiap tiga minggu sekali ada petugas dari divisi budidaya PT. Sirtanio Organik Indonesia yang selalu memberikan pelatihan pembuatan saprodi (pupuk organik dan agen hayati), mengontrol lahan dan memberikan informasi kepada petani mitra. Petani mitra juga memiliki keterbatasan untuk mengikuti pelatihan pembuatan saprodi dikarenakan kondisi fisik yang tidak memungkinkan dan lokasi petani mitra yang cukup jauh dengan tempat pelatihan diadakan sehingga petani mitra lebih memilih untuk mengurus lahannya daripada untuk datang menghadiri pelatihan pembuatan saprodi.

\section{Kondisi Lahan}

Kondisi Lahan memiliki nilai signifikansi sebesar 0,754 $(>0,1)$ hal ini menunjukkan bahwa kondisi lahan merupakan salah satu faktor yang tidak berpengaruh signifikan terhadap keputusan petani untuk bermitra. Kondisi lahan tidak berpengaruh signifikan terhadap keputusan petani untuk bermitra dikarenakan pada kondisi di lapang petani yang kondisi lahannya tidak memenuhi syarat untuk bermitra dengan PT. Sirtanio Organik Indonesia terutama dalam hal sumber irigasi masih bisa ditanggulangi oleh pembuatan filter pada lahan mereka sehingga air tidak langsung masuk ke lahan tetapi melewati bak penampungan atau filter terlebi dahulu, hal tersebut dapat mengurangi residu yang dibawa oleh air yang bukan berasal dari sumber.

\section{KESIMPULAN DAN SARAN}

Berdasarkan hasil penelitian dan analisis yang dilakukan, maka dapat disimpulkan bahwa 
Fakhruddin Y., Triana D. H.: Faktor-Faktor yang Mempengaruhi ...

Karakteristik sosial ekonomi dan ekologi petani mitra PT. Sirtanio Organik Indonesia sebagian besar adalah laki-laki di usia produktif dengan jenjang pendidikan SD sederajat memiliki jumlah anggota keluarga 3 hingga 4 orang, memiliki cukup pengalaman dengan status lahan milik sendiri namun masih dalam kategori sempit serta mendapatkan modal dari dana pribadi dan kredit PT. Sirtanio Organik Indonesia serta kondisi lahan yang sudah memenuhi syarat untuk menerapkan pertanian organik. Faktor-faktor yang berpengaruh signifikan terhadap pengambilan petani untuk bermitra dengan PT. Sirtanio Organik Indonesia adalah umur, pendidikan, luas lahan, dan pendapatan. Adanya bantuan kredit berupa sarana filter irigasi dari PT. Sirtanio Organik Indonesia agar petani yang memiliki lahan diluar saluran irigasi dari sumber air tertarik untuk menjalin kemitraan sehingga jumlah petani mitra terus berkembang setiap musim tanam.

\section{DAFTAR PUSTAKA}

Fachruddin, A.A. 2013. Faktor-Faktor Yang Mempengaruhi Keputusan Petani Tembakau Untuk Bermitra Dengan Koperasi Agrobisnis Tarutama Nusantara Melalui Koperasi Margi Utama. Tidak Diterbitkan. Skripsi. Jember. Program Studi Agribisnis Fakultas Pertanian Universitas Jember.

Gani dan Siti Amalia. 2015. Alat Analisis Data : Aplikasi Statistik untuk Penelitian
Bidang Ekonomi dan Sosial. Yogyakarta : ANDI. Gujarati, Damodar. 2007. Dasar-dasar Ekonometrika. Jakarta: Erlangga.

Indraningsih, K. S. 2011. Pengaruh Penyuluhan Terhadap Keputusan Petani dalam Adopsi Inovasi Teknologi Usahatani Terpadu. Agroekonomi. Vol. 29(1): 1-24.

Mayrowani, Heni. 2012. Pengembangan Pertanian Organik di Indonesia. Forum Penelitian Agro Ekonomi, 30(2): 91-108.

Rogers, E. M. 1983. Diffusion of Innovations. New York: Free Press.

Rosadi, Dedi. 2011. Analisis Ekonometrika \& Runtun Waktu Terapan dengan $R$. Yogyakarta: ANDI.

Soekartawi. 1988. Prinsip Dasar Komunikasi Pertanian. Jakarta: UI-Press.

Sugiyono. 2016. Metode Penelitian Manajemen. Bandung: Alfabeta.

Suhardianto A, Baliwati YF, Sukandar D. 2007. Ketahanan Pangan Rumah tangga Petani Penghasil Beras Organik. J.Gizi dan Pangan, 2(3): 1-12.

Valentine, Bella Dyah. 2017. Faktor-Faktor Yang Mendasari Pengambilan Keputusan Petani Tebu Bermitra Dengan PG. Djatiroto. Diterbitkan. Skripsi. Jember. Program Studi Agribisnis Fakultas Pertanian Universitas Jember. 